\title{
Bacteria colonising Penstemon digitalis show volatile and tissue- specific responses to a natural concentration range of the floral volatile linalool
}

\author{
Rosalie C. F. Burdon ${ }^{1} \cdot$ Robert R. Junker $^{2} \cdot$ Douglas G. Scofield $^{3,4} \cdot$ Amy L. Parachnowitsch ${ }^{1}$ (i)
}

Received: 18 December 2017 / Accepted: 22 February 2018 / Published online: 1 March 2018

(c) The Author(s) 2018. This article is an open access publication

\begin{abstract}
Bacteria on floral tissue can have negative effects by consuming resources and affecting nectar quality, which subsequently could reduce pollinator visitation and plant fitness. Plants however can employ chemical defences to reduce bacteria density. In North American, bee-pollinated Penstemon digitalis, the nectar volatile $S$-(+)-linalool can influence plant fitness, and terpenes such as linalool are known for their antimicrobial properties suggesting that it may also play a role in plant-microbe interactions. Therefore, we hypothesized linalool could affect bacterial growth on $P$. digitalis plants/flowers. Because $P$. digitalis emits linalool from nectar and nectary tissue but not petals, we hypothesised that the effects of linalool could depend on tissue of origin due to varying exposure. We isolated bacteria from nectary tissue, petals and leaves, and compared their growth relative to control using two volatile concentrations representing the natural emission range of linalool. To assess whether effects were specific to linalool, we compared results with the co-occurring nectar volatile, methyl nicotinate. We show that response to floral volatiles can be substance and tissue-origin specific. Because linalool could slow growth rate of bacteria across the $P$. digitalis phyllosphere, floral emission of linalool could play a role in mediating plant-bacteria interactions in this system.
\end{abstract}

Keywords Anti-microbial $\cdot$ Phyllosphere $\cdot$ Plant defence $\cdot$ Scented nectar $\cdot$ Volatile organic compounds (VOCs)

Communicated by Marko Rohlfs.

Electronic supplementary material The online version of this article (https://doi.org/10.1007/s00049-018-0252-x) contains supplementary material, which is available to authorized users.

Amy L. Parachnowitsch

amyparachnowitsch@gmail.com

1 Department of Plant Ecology and Evolution, Evolutionary Biology Centre, Uppsala University, Norbyvägen 18d 75236 Uppsala, Sweden

2 Department of Biosciences, University Salzburg, Hellbrunnerstr. 345020 Salzburg, Austria

3 Department of Evolutionary Biology, Evolutionary Biology Centre, Uppsala University, Norbyvägen 18d 75236 Uppsala, Sweden

4 Uppsala Multidisciplinary Center for Advanced Computational Science, Uppsala University, 75105 Uppsala, Sweden

\section{Introduction}

Microbes colonising plant tissues are common and can have a range of effects from mutualistic to antagonistic. In the context of flowers and nectar, these microbes can also influence interactions with mutualistic pollinators (Aleklett et al. 2014). While nectar yeasts may attract pollinators (Schaeffer and Irwin 2014), thus far nectar bacteria have shown negative effects on pollinator-interactions (Vannette et al. 2013; Good et al. 2014). However, plants are not helpless and can deploy defences against microbes colonising important reproductive structures, such as emitting floral volatiles with anti-microbal properties (Junker and Tholl 2013). For example, in Arabidopsis thaliana the floral volatile $(E)$ - $\beta$ caryophyllene can directly inhibit the growth of pathogenic bacteria colonising stigma tissue (Huang et al. 2012). Common floral volatiles such as terpenoids and nitrogen-containing alkaloids also have antimicrobial properties (Griffin et al. 1999; Sansores-Peraza et al. 2000; Queiroga et al. 2007) but these are often tested against lab bacteria strains rather than ecologically relevant bacteria. More generally, antimicrobial 
activity of essential oils rich in volatiles common to both vegetative and floral tissues is well known (Hammer et al. 1999; Dorman and Deans 2000; Höferl et al. 2009) and volatiles can also mediate microbe interactions in soil (Effmert et al. 2012), suggesting that volatiles in floral scent bouquets may play a role in plant-microbe interactions.

Flowers generally emit the highest amounts and most diverse blends of volatile organic compounds (VOCs) across plant organs (Knudsen et al. 2006; Dudareva et al. 2013). Differences in chemical composition across the phyllosphere could enforce selective environments for the establishment and growth of microorganisms (Del Giudice et al. 2008; Junker et al. 2011). For example, the floral volatiles phenylacetonitrile and 2-phenylethyl alcohol inhibit growth of bacteria originating from Saponaria officinalis leaves much more efficiently than bacteria isolated from flowers of the same species, suggesting that floral volatiles could influence bacteria composition among tissues (Junker et al. 2011). It may be particularly important to control bacteria found in nectar rewards because bacteria can degrade nectar or effect flower signals such as scent and subsequently affect pollination (Canto and Herrera 2012; Vannette et al. 2013; Good et al. 2014; Rering et al. 2017; Helletsgruber et al. 2017). Therefore, emission from specific tissues such as flowers or volatiles in nectar could affect in the reproductive success of plants via microbe interactions (Aleklett et al. 2014).

Although volatiles can have anti-microbial properties, microbe responses to secondary metabolites can be strainand volatile-specific, or dependent on volatile concentration (Junker and Tholl 2013; Vannette and Fukami 2016). For instance, caffeine inhibits the growth and density of nectar microbes specifically at high concentrations, whereas aucubin increases the growth rate of microbes (Vannette and Fukami 2016). Furthermore, not all plant-microbe interactions are anti-microbial in nature; some bacteria found in the soil are adapted to metabolise VOCs as a carbon source (Kleinheinz et al. 1999; Del Giudice et al. 2008), but this is yet to be shown for bacteria in the phyllosphere. Therefore, we tested whether floral volatiles can suppress or facilitate the growth and density of plant-associated bacteria. Additionally we tested whether bacteria could use floral volatiles as a carbon source for growth.

We isolated bacterial communities from the leaves, petals, and nectary tissue of Penstemon digitalis, which vary in their exposure to $(S)-(+)$-linalool (hereafter 'linalool') emitted from the nectary and nectar (Parachnowitsch et al. 2013; Burdon et al. 2015). We hypothesized that field-collected bacteria colonizing $P$. digitalis plant tissues could differ in their response to the presence of linalool because they are exposed to different levels in natural conditions. From each tissue, we randomly selected individual bacterial strains to assess their growth rate and maximum density in control and floral volatile-exposed conditions. We focused our investigations on linalool for four reasons: first, linalool is one of the most common volatiles emitted as floral scent across angiosperms (Knudsen et al. 2006); second, linalool has been shown to have antimicrobial properties (Queiroga et al. 2007): third, in P. digitalis linalool was previously identified as a target of phenotypic selection with high emitters having increased reproductive success (Parachnowitsch et al. 2012); and fourth, of the abundant scents making up the floral bouquet only linalool can directly protect nectar because it is also found in the nectar (Parachnowitsch et al. 2013). We tested linalool's antimicrobial or facilitation effects at a concentration range based on field emissions. To determine whether any effects were due to linalool or simply due to the presence of any floral volatile, we compared linalool's effects to that of methyl nicotinate, using the same concentration range. While methyl nicotinate effects on plant reproduction and emission strength are unknown for $P$. digitalis, it is an ecologically relevant comparison because methyl nicotinate has been detected in targeted scent collections from nectar (Burdon et al. 2015). However, because methyl nicotinate is not detected in general floral bouquet sampling (Parachnowitsch et al. 2012), it suggests the concentration is much lower than linalool's within the flower.

\section{Methods and materials}

\section{Bacteria isolation and identification}

We sampled three distinct bacterial microhabitats from the flowers and leaves of Penstemon digitalis plants $(n=3$ plants: 2 flowers (one male phase and one female phase to cover the age span of the flowers) and 1 leaf per plant, Ithaca, New York, Aug 2014). For each flower, flower corollas were separated into two parts, the scentless flower petals and the volatile-emitting nectary (Burdon et al. 2015). Because $P$. digitalis produces relatively low amounts of nectar (Junker and Parachnowitsch 2015), samples from the nectar alone were difficult to obtain from the field. A single sample yielded one bacteria strain that was identified (see "Results"), but was not included in further tests due to lack of replication. However, when collecting nectar, pollinators encounter bacteria in the corolla tube along with nectar due to the constricted corolla tube of $P$. digitalis so wholenectary samples represent what bacteria could be dispersed into/found in the nectar. Tissue samples were preserved individually in $1.5 \mathrm{ml}$ Screw Cap micro tubes (BRAND ${ }^{\circledR}$, Sigma Aldrich) containing $500 \mu$ lysogeny broth (LB). All sampling equipment was sterilized with ethanol before sampling. Bacteria were allowed to grow for $12 \mathrm{~h}$ prior to adding $750 \mu \mathrm{l}$ glycerin and preserving at $-80{ }^{\circ} \mathrm{C}$ until use. To separate bacteria from plant material, tissues were sonicated ( $7 \mathrm{~min}$ ) and then vortexed. A $2 \mu 1$ 1:100 LB dilution of each 
sample was grown on LB agar plates (LB-Medium Powder, AppliChem, Darmstadt, Germany; Bacto Agar, Becton, Dickinson and Company, Sparks, USA), containing fungicide Cycloheximide (Sigma-Aldrich, Steinheim, Germany, $30 \mu \mathrm{g} / \mathrm{l})$ (Junker et al. 2014). After plate incubation at $24{ }^{\circ} \mathrm{C}$ for $72 \mathrm{~h}$, bacterial strains were distinguished based on colour, shape, reflectance and texture. Distinct morphs (hereafter 'strains') were cultivated on separate LB agar plates containing no fungicide $(n=81)$, of which 47 strains were randomly selected for identification.

To identify bacteria, DNA was extracted and multiplied by PCR using primers to anneal with conserved regions of bacterial 16S rRNA genes. The lysates were centrifuged at $14,000 \mathrm{~g}$ for $3 \mathrm{~min}$ and the supernatant containing bacterial DNA acted as template for polymerase chain reaction (PCR). DNA of one colony per strain was extracted using the High Pure PCR Template Preparation kit (Roche, GrenzachWyhlen, Germany) following the manufacturer's instructions. The following conditions were used for extraction: $1 \mu \mathrm{l}$ genomic DNA was dissolved in $21.9 \mu \mathrm{l}$ sterile distilled water (dH20), $6 \mu$ of 10-fold reaction buffer (Moltaq PCR kit, Molzym GmbH and Co.KG, Bremen, Germany) and $10 \mathrm{mM}$ dNTP-mix (Thermo Scientific, Munich, Germany). We added $1 \mu \mathrm{l}$ of forward primer (27f), $1 \mu \mathrm{l}$ of reverse primer (1492r) (Metabion, Martinsried, Germany) and $0.3 \mu \mathrm{l} \mathrm{Taq}$ polymerase (Molzym) giving a total volume of $\sim 30 \mu \mathrm{l}$ per sample (Junker et al. 2014). A thermocycler (Eppendorf Mastercycler gradient, Hamburg, Germany) with the following programme was used: initial denaturation at $94{ }^{\circ} \mathrm{C}$ for $3 \mathrm{~min}, 35$ cycles of $94{ }^{\circ} \mathrm{C}$ for $30 \mathrm{~s}, 52{ }^{\circ} \mathrm{C}$ for $30 \mathrm{~s}, 72{ }^{\circ} \mathrm{C}$ for $100 \mathrm{~s}$ and a final extension step at $72{ }^{\circ} \mathrm{C}$ for $5 \mathrm{~min}$. Positive and negative controls with and without genomic DNA were made for each set of samples during the PCR. PCR products were purified with the Wizard SV Gel and PCR clean-up kit (Promega, USA) according to the instructions of the producer. DNA concentration was measured using a NanoDrop-ND-1000 (NanoDrop Technologies, Wilmington, USA), and a total of $375 \mathrm{ng}$ of DNA along with $2 \mu \mathrm{l}$ primer $1492 \mathrm{r}(20 \mathrm{pM}$ ) were sent to Eurofins Genomics (Ebersberg, Germany) for Extended HotShot sequencing. Sequences were quality start- and end-trimmed according to phred scores with 4Peaks (Nucleobytes, Amsterdam, NL) (see Junker et al. 2011 for further experimental detail). Bacterial strains $(n=47)$ were taxonomically assigned to the lowest taxonomical level possible via the GenBank nucleotide database (accessed 20th February 2015) (Benson et al. 2013): Accession numbers: KX891497-KX891543.

\section{Volatile bioassays and volatiles as a carbon source}

To determine the effect of linalool and methyl nicotinate on bacterial growth rate and maximum density, we tested bacteria strains using natural linalool emissions of low (5 ng/ $\mathrm{ml})$ and high $(100 \mathrm{ng} / \mathrm{ml})$ concentrations in basic nutrient media (SRM + glucose) (Del Giudice et al. 2008). Media consisted of $0.75 \mathrm{~g}$ ammonium dihydrogen phosphate (Merck, Darmstadt, Germany), 0.15 g potassium chloride salt (Roth, Karlsruhe, Germany), and $0.15 \mathrm{~g}$ magnesium sulphate (Alfa Aesar GmbH, Karlsruhe, Germany) for SRM and $0.75 \mathrm{~g}$ glucose (Sigma Aldrich $\left.{ }^{\circledR}\right) / 750 \mathrm{ml}$ distilled water (unless otherwise noted). Prior to resolved identification of the strains we randomly selected and tested eight nectary, ten petal and five leaf strains $(n=23)$. Constraints for growing bacteria prevented testing all 47 strains and one selected strains failed to grow (see Table 1 , giving final $n=22$ ). To determine volatile concentrations that reflect plant emissions, we used measurements of linalool emissions from two common gardens of $P$. digitalis in 2012 from the same populations where we collected bacteria samples and other base-line data on the species (Parachnowitsch et al. 2012; Burdon et al. 2015). The average linalool emitted from 86 $P$. digitalis inflorescences was $44 \pm 4 \mathrm{ng}$ with a range from $<5 \mathrm{ng}$ to few plants producing over $100 \mathrm{ng}$. We chose to use the same concentration range for methyl nicotinate as a direct volatile treatment comparison, although it is emitted at much lower amount than linalool in $P$. digitalis flowers (Burdon et al. 2015). We conducted two types of volatile bioassay: (1) to test for suppression/facilitation of volatiles, bioassays contained either low or high volatile concentrations (5 vs $100 \mathrm{ng}$ ) in SRM + glucose media and (2) to test whether bacteria could metabolise volatiles as a carbon source bioassays were run with volatiles only and no glucose. As a control, we also tested all strains SRM + glucose media without volatiles. Racemic linalool and methyl nicotinate used were from Sigma Aldrich ${ }^{\circledR}$.

To prepare the bacteria samples, we transferred one colony per bacterial strain from agar plates into $1 \mathrm{ml}$ volatile treated/control SRM and took an initial optical density measurement at $600 \mathrm{~nm}\left(\mathrm{OD}_{600}\right)$ (Biotek ELX808, software Gen5 version 2.04). Bacteria solutions were transferred into 96-well microwell plates (A. Hartenstein) ( $n=7$ replicates/ strain, 11-12 strains/plate), with a standardised initial $\mathrm{OD}_{600}$ of 0.01 across strains and treatments. Per 96-well microwell plate, we included a media only row as a within-plate control. To prevent bacterial settling, plates were kept incubated at $28{ }^{\circ} \mathrm{C}$ and gently shaken at $270 \mathrm{rpm}$ (Grant-bio PHMP-4 Thermo-Shaker). Optical density measurements were taken hourly $(0-12 \mathrm{~h})$ to determine growth rate and recorded 3-6 h thereafter until bacteria reached an asymptote (within $30 \mathrm{~h}$ ). The lids of the plates were treated with Triton X-PO in 20\% ethanol (Sigma Aldrich ${ }^{\circledR}$ ) to prevent condensation and false OD readings. The above methods were repeated with SRM without glucose to assess if any bacterial strain could use linalool or methyl nicotinate as an alternative carbon source. The basic media was autoclaved $\left(125^{\circ} \mathrm{C} / 35 \mathrm{~min}\right)$ prior to volatile inoculation. 
Table 1 Bacterial strain identification

\begin{tabular}{|c|c|c|c|}
\hline Species & $\begin{array}{l}\text { Number of } \\
\text { strains (number } \\
\text { tested) }\end{array}$ & BLAST identity & References \\
\hline \multicolumn{4}{|l|}{ Leaf tissue } \\
\hline Bacillus safensis & $5(3)$ & 1 & $\begin{array}{l}\text { Identified from spacecraft surfaces (Satomi 2006) and detected in Asphode- } \\
\text { lus aestivus and Capsodes infuscatus nectar (Samuni-Blank et al. 2014) as } \\
\text { well as Citrus paradisi (Fridman et al. 2012) }\end{array}$ \\
\hline Pantoea agglomerans & $1(1)$ & 0.99 & $\begin{array}{l}\text { Thought to be non-pathogenic to plants and used as biocontrol agent (John- } \\
\text { son et al. 2000) and found in Amygdalus communis (Fridman et al. 2012) } \\
\text { and Capsodes infuscatus nectar (Samuni-Blank et al. 2014) }\end{array}$ \\
\hline Pantoea eucalypti & $1(1)$ & 0.99 & $\begin{array}{l}\text { Isolated from blight in eucalyptus (Brady et al. 2009) and found in nectar } \\
\text { (Samuni-Blank et al. 2014) }\end{array}$ \\
\hline Pseudomonas oryzihabitans & $1(0)$ & 0.98 & Growth promotion for potato plants by iron capture (Sessitsch et al. 2004) \\
\hline \multicolumn{4}{|l|}{ Petal tissue } \\
\hline Erwinia aphidicola & $2(0)$ & 0.99 & Pathogenic to aphids and plants (Grenier et al. 2006; Santos et al. 2009) \\
\hline Erwinia persicina & $1(0)$ & 0.99 & $\begin{array}{l}\text { Non-pathogenic (Hao et al. 1990) and found in nectar (Fridman et al. 2012; } \\
\text { Samuni-Blank et al. 2014) }\end{array}$ \\
\hline Erwinia sp. & $1(0)$ & & \\
\hline Ewingella americana & $2(2)$ & $0.97-0.99$ & Pathogenic to mushrooms (Inglis et al. 1996) \\
\hline Pantoea agglomerans & $7(2)$ & $0.98-0.99$ & See above \\
\hline Pantoea eucalypti & $4(2)$ & 0.97 & See above \\
\hline Pantoea vagans & $2(1)$ & 0.99 & Biocontrol against fire blight (Kamber et al. 2012) \\
\hline Rosenbergiella collisarenosi & 1 (growth failed) & 0.99 & Isolated from floral nectar (Lenaerts et al. 2014) \\
\hline \multicolumn{4}{|l|}{ Nectary tissue } \\
\hline Acinetobacter bereziniae & $1(1)$ & 0.80 & $\begin{array}{l}\text { Non-pathogenic, evidence for plant growth promotion (Martínez-Rodríguez } \\
\text { et al. 2014) }\end{array}$ \\
\hline Acinetobacter nectaris & $3(1)$ & 0.98 & $\begin{array}{l}\text { Isolated from nectar (Álvarez-Pérez et al. 2013; Jacquemyn et al. 2013; } \\
\text { Samuni-Blank et al. 2014; Bartlewicz et al. 2016) }\end{array}$ \\
\hline Erwinia rhapontici & $1(1)$ & 0.93 & Pathogenic to many plants (Feistner et al. 1983) \\
\hline Pantoea agglomerans & $5(5)$ & $0.98-0.99$ & See above \\
\hline Pantoea ananatis & $1(0)$ & 0.99 & $\begin{array}{l}\text { Common plant pathogen in agricultural crops and forest tree species world- } \\
\text { wide (Coutinho and Venter 2009) }\end{array}$ \\
\hline Pantoea eucalypti & $1(0)$ & 0.99 & See above \\
\hline
\end{tabular}

\section{Statistical analysis}

We fit bacterial growth curves using the $\mathrm{R}$ package grofit (Kahm et al. 2010) as has been used in other studies for nectar microbes (e.g. Vannette and Fukami 2016). Grofit selects the best fit model using Akaike's Information Criterion (AIC) and these were visually confirmed, and where appropriate, model returns of NA were adjusted to zeros to reflect where bacteria did not grow. We used the estimated parameters $\mu\left(\mathrm{h}^{-1}\right)$ the maximum growth rate and $A\left[\mathrm{OD}_{600}\right]$ the asymptote of the growth curve, which is the maximum density reached. Both growth rate and maximum density likely influence the ability of bacteria to compete and disperse in ephemeral floral tissues/nectar.

To assess the response of bacteria to linalool and methyl nicotinate relative to the control, we fit mixedeffect models for growth rate $(\mu)$ or density $(A)$ as the response variable and volatile concentration (control, $5 \mathrm{ng}$, $100 \mathrm{ng}) \times$ tissue origin (leaf, petal, nectary) as explanatory variables and bacteria strain, genera, and species as random effects. To assess differences among treatments within tissue origin, we ran separate ANOVAs for each tissue type followed by Tukey post hoc tests. We excluded from analysis Rosenbergiella collisarenosi because fewer than three replicates' growth curves could be estimated in the control. We performed separate mixed effect models for linalool and methyl nicotinate, however, to test whether these two volatiles differed in their effects we grew the strains with $100 \mathrm{ng}$ of either volatile at the same time and compared these. No strain of bacteria grew in the volatile without glucose treatments and so no further analysis was conducted using these data. Statistical analyses were performed in $R$ (R Core Team 2017). 


\section{Results}

\section{Bacteria isolation and identification}

From the phyllosphere of $P$. digitalis plants we identified 13 species of bacteria representing 7 genera (Table 1). From leaf surfaces we identified four species of bacteria from eight isolated strains, from petals seven species from 20 isolated strains and from nectary tissue seven species from 19 strains. The most ubiquitous species were Pantoea agglomerans and $P$. eucalypti, which were present on both leaves and flowers. Leaf tissue strains also included Bacillus safensis and Pseudomonas oeyzihabitans that were lacking on the flower samples. In addition to $P$. agglomerans and $P$. eucalypti, both petal and nectary tissue had members of the genus Erwinia but with different species. The scentless petals also had species of Ewingella, and Rosenbergiella while species of Acinetobacter were only detected in the nectary samples and the one strain from nectar was also A. nectaris. Although we found genera composition differed between tissues (Table 1), the differences in bacterial colonization between the tissues are based on few cultivatable strains; further assessments of bacterial communities from cultivation-independent methods would be required to examine differences in tissue diversity.

\section{Volatile bioassays}

In general, linalool had a greater effect on bacteria than methyl nicotinate and the effects were tissue-origin specific. While bacteria isolated from leaves were not affected by linalool, growth was slower for both petal and nectary isolates when linalool was added (Fig. 1; Table 2). Likewise, the maximum density of leaf isolates was not affected by linalool, while for petal and nectary isolates the low linalool treatment actually increased maximum density (Fig. 1; Table 2). Linalool concentration did not have an additive effect on either growth or density; slower growth at higher linalool concentration was only seen for petal isolates and only small amounts of linalool facilitated increase density. Overall leaf isolates did more poorly than those from floral tissues.

Table 2 ANOVA table of fixed effects for bacterial growth and density in control, 5 and $100 \mathrm{ng}$ volatile conditions

\begin{tabular}{lllr}
\hline Model & Fixed effects & $F$ & $P$ \\
\hline Linalool models $(N=349)$ & & \\
Maximum growth & Volatile concentration & $F_{2,348}=33.03$ & $<0.001$ \\
& Tissue origin & $F_{2,348}=6.28$ & 0.011 \\
& Volatile $\times$ tissue & $F_{4,348}=4.17$ & 0.0026 \\
Maximum density & Volatile concentration & $F_{2,348}=4.39$ & 0.013 \\
& Tissue origin & $F_{2,348}=5.38$ & 0.023 \\
& Volatile $\times$ tissue & $F_{4,348}=10.36$ & $<0.001$ \\
Methyl nicotinate models $(N=377)$ & & \\
Maximum growth & Volatile concentration & $F_{2,376}=9.83$ & $<0.001$ \\
& Tissue origin & $F_{2,376}=5.41$ & 0.018 \\
& Volatile $\times$ tissue & $F_{4,376}=8.86$ & $<0.001$ \\
Maximum density & Volatile concentration & $F_{2,376}=2.91$ & 0.056 \\
& Tissue origin & $F_{2,376}=5.72$ & 0.015 \\
& Volatile $\times$ tissue & $F_{4,376}=1.50$ & 0.20 \\
\hline
\end{tabular}

Strain, genus and species were included as random effects
Fig. 1 a The maximum growth rate $(\mu)$ and $\mathbf{b}$ maximum density $(A)$ for bacteria strains isolated from $P$. digitalis plants cultured in control or with the floral volatile linalool. Linalool concentrations are ecologically relevant for inflorescence emission variation and tissue origin arranged from low emitting tissues (leaf) to high (nectary). Statistical tests in Table 2; we show the boxplots to demonstrate the full range of the data, means, standard errors, and sample sizes found in Supplementary Table 1. Letters represent within tissue post hoc tests to determine differences among growth media
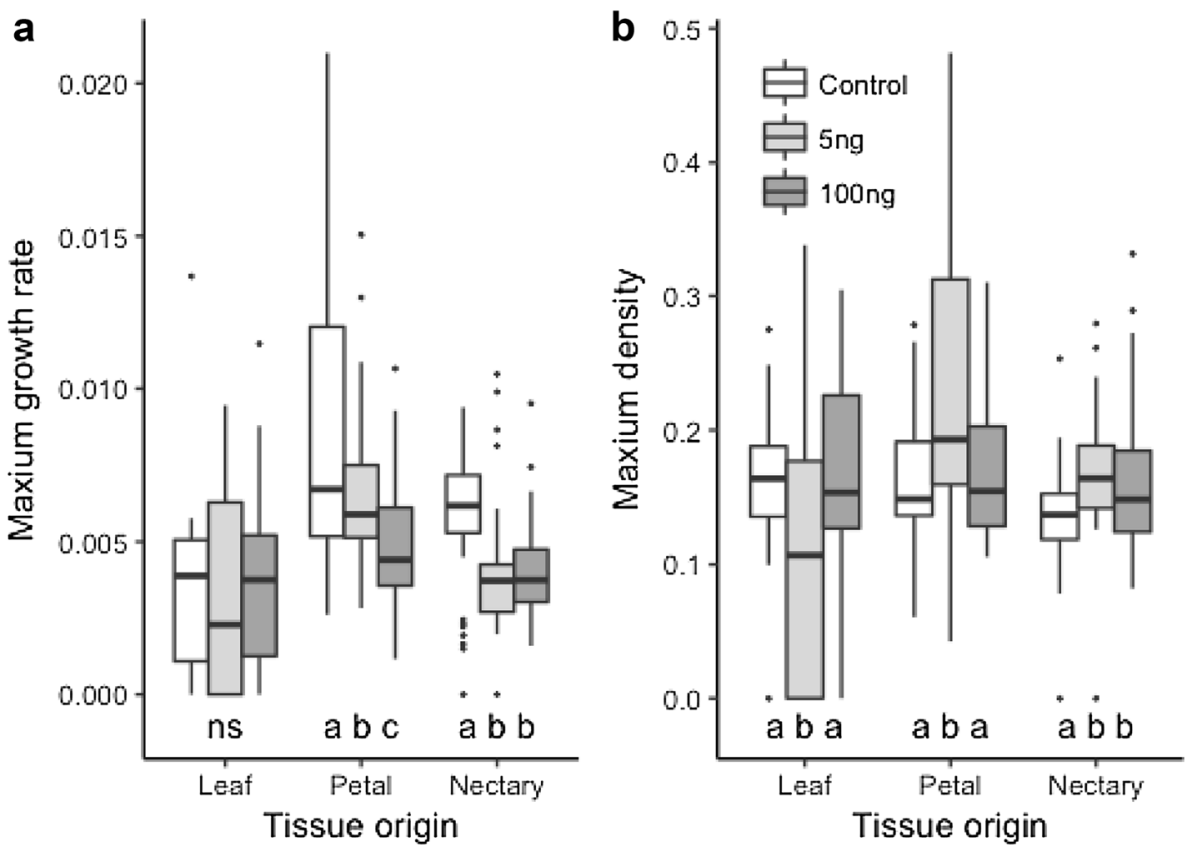
Methyl nicotinate had little effect on bacterial growth rate or maximum density. As was seen for linalool, leaf isolates were never strongly affected by methyl nicotinate but there was some reduction in growth rate at the ecologically high levels of methyl nicotinate for petal and nectary isolates (Fig. 2; Table 2). Unlike linalool, maximum density was not affected by methyl nicotinate (Table 2). When growing bacteria in high concentrations of linalool and methyl nicotinate, we found a significant difference in maximum growth between the substances $\left(F_{1,236}=31.79, P<0.001\right)$ but not density $\left(F_{1,236}=0.079, P=0.78\right)$.

\section{Discussion}

In our study, leaves and flowers of $P$. digitalis were colonized by bacteria commonly described in other plants (Table 1), although plant species can differ substantially in the bacteria detected, for example in nectar (Álvarez-Pérez et al. 2012). Addition of linalool inhibited bacterial growth rate significantly compared to control media and methyl nicotinate treatments. Antimicrobial effects of linalool have been shown previously (e.g. Queiroga et al. 2007; Kamatou and Viljoen 2008; Taniguchi et al. 2014; Herman et al. 2016) and our results show that linalool can also affect bacteria collected from wild plants at ecologically relevant concentrations. In particular, as a nectar component, linalool could play a more complex role in plant-pollinator interactions if its effects on nectar microbes alter pollinator behaviour. However, linalool might even facilitate density for some bacteria at low concentrations (Fig. 1) suggesting more detailed experiments are needed to tease apart its role. Furthermore, our study focused on bacteria, while yeasts are also commonly to nectar and linalool may affect their growth in this system. More generally, Penstemon whole plant extracts show antimicrobial activity (Zajdel et al. 2012a, b, 2013) and our results suggest that floral volatiles, at least linalool, may be an additional important compound for plant-microbe interactions.

It is often assumed the primary function of floral volatiles is the attraction of pollinators (Wright and Schiestl 2009). However, floral volatiles are increasingly being shown to aid floral defence (Kessler and Baldwin 2007; Theis et al. 2007; Junker and Bluthgen 2008), including defence against surface-dwelling pathogens (Huang et al. 2012). Bacteria are known to degrade nectar sugars, alter nectar pH (Herrera et al. 2008; Vannette et al. 2013) and nectar microbes can disrupt pollination and reduce plant fitness (Junker et al. 2014). Defending floral tissues from such microorganisms could thus be crucial to plants (Fridman et al. 2012; Huang et al. 2012; Bulgarelli et al. 2013). Our work supports the hypothesis that in addition to attracting pollinators or repelling antagonists, floral scents could play a role in plant-microbe interactions. For example, $P$. digitalis increases emission strength of linalool during the day possibly to attract day active pollinators such as bumblebees (Burdon et al. 2015), however daytime is also when temperatures rise and conditions facilitate floral bacterial growth.

We found the effects of floral volatiles on bacterial growth rate or maximum density often depended on tissue origin. Strain specific variation in growth rate to different volatiles or concentrations is not new (Vannette and Fukami 2016). For bacteria, different genera and strains/species within genera can differ in metabolic capability, nutritional requirements and adaption to environmental stresses including oxidative stress from VOCs (Lindow and Brandl 2003; Lievens et al. 2015). For example, A. nectaris appears to be a nectar specialist that metabolises specific sugars and amino acids
Fig. 2 a The maximum growth rate $(\mu)$ and $\mathbf{b}$ maximum density (A) for bacteria strains isolated from $P$. digitalis plants cultured in control or with the nectar volatile methyl nicotinate. Concentrations reflect the range for linalool emission for comparison, and are much higher than natural nectar emission of methyl nicotinate in $P$. digitalis; control treatment is the same as Fig. 1. Statistical tests in Table 2; means, standard errors, and sample sizes found in Supplementary Table 1. Letters represent within tissue post hoc tests to determine differences among growth media
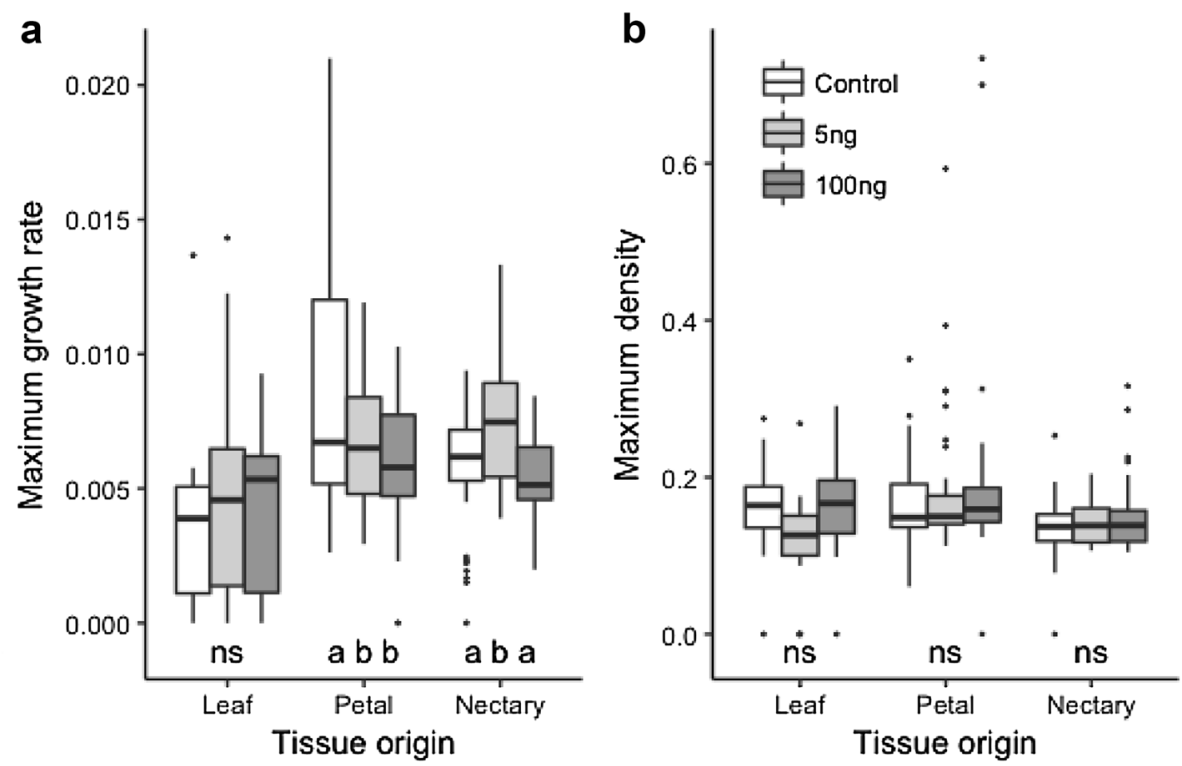
at temperatures between 25 and $30{ }^{\circ} \mathrm{C}$ compared with other Acinetobacter species (Álvarez-Pérez et al. 2013). Here, we found floral bacteria strains were generally more sensitive to floral volatiles compared to leaf strains. Thus, tolerance to floral volatiles could impact bacterial strain establishment on different tissues and affect bacterial community composition or competitive ability within communities (Lindow and Brandl 2003; Lievens et al. 2015). Our results ran contrary to our hypothesis, suggesting that those bacteria found in close proximity to linalool production are not tolerant and its presence may modulate bacterial growth in the flower and nectar by slowing growth. However, maximum density was not suppressed by linalool (or methyl nicotinate) suggesting that volatile effects on microbial communities need further investigation to understand their impacts within the flower, especially in a constantly changing resource such as nectar. One possibility is bacterial growth rate may be more important for determining successful colonization of wildflowers than maximum density because nectar resources are ephemeral and microbe communities may not have time to reach maximum density. However, we need relevant field testing to assess whether these factors help explain differences in effects of linalool in our system.

We found none of the isolated bacterial strains metabolized volatiles as their sole carbon source (not shown because all had zero growth), but some strains grew more with volatiles present when concentrations were low when sugar was also available. If floral volatiles are employed as a microbial defence, bacteria tolerance to volatiles could have detrimental effects on plant fitness. For example, nectar specialist microbes can alter floral volatiles and subsequent plant-pollinator interactions (Vannette and Fukami 2016; Rering et al. 2017; Helletsgruber et al. 2017). While we did not measure volatile concentration after bacterial growth, the nectar specialist $A$. nectaris is the most likely candidate to affect volatile strength in nectar. In this scenario an arms race between plants and microbes could drive selection on increased strength of volatiles emitted by the plant similar to the selection on linalool we observed in the field (Parachnowitsch et al. 2012). Future work should explore if bacteria are capable of driving selection on VOCs by comparing how suppression or facilitation of bacteria can negatively or positively affect plant reproduction (Huang et al. 2012; Junker and Tholl 2013; McArt et al. 2014).

Our lab experiments may not represent tissue communities on $P$. digitalis plants for four reasons. First, cultivation technique likely biased the bacteria included in our study because all isolation media, extraction procedures and incubation methods are selective to some extent. For example, Yang et al. (2001) showed that only a small proportion of bacteria associated with plant surfaces cultivate on standard media. Second, our volatile bioassays were conducted on bacterial strains, while in nature bacteria rarely occur in isolation. Although our technique allowed for direct comparisons of bacteria responses to volatiles at different concentrations, competition in natural communities would likely lead to exclusion of strains over time (Lindow and Brandl 2003). Here, $P$. agglomerans is of particular interest because it was present across all tissues and is known to outcompete and suppress other tissue dwelling bacteria (Johnson et al. 2000). Suggestive of this competition was that more strains from female-phase flowers were identified as P. agglomerans compared to male-phase flowers in our protandrous species however, more detailed sampling and controlled experiments are necessary to determine if bacteria competition occurs in the flowers as they age. Third, we tested racemic linalool here while $P$. digitalis produces only $(S)-(+)$-linalool in the flowers. Some basic testing shows anti-microbial properties of linalool enantiomers may vary (Schmidt et al. 2005) so our results should be viewed with caution. Fourth, the 'nectar' was constant throughout our trials unlike the depleted and replenished nectar resource of flowers, which could have affected the growth and density patterns we observed. However, our results do show a marked difference between the two main nectar volatiles with racemic linalool having a much greater effect on bacteria than methyl nicotinate, even at such elevated levels of methyl nicotinate. These results are suggestive of a role in plant-microbe interactions for linalool in our system.

\section{Conclusion}

Here we show that linalool could defend $P$. digitalis tissues by slowing the growth rate of specific bacteria, raising the possibility that plant-microbe interactions may influence selection on this volatile. Our work adds to the growing body of research that suggests alternative functions beyond pollinator attraction for floral volatiles. Further work could help to address why flowers produce floral scents when scent is expected to play little role in plant-pollinator interactions, such as bird-pollinated or self-pollinated flowers.

Acknowledgements The study was supported by Kungliga Vatenskapsakademien (The Royal Swedish Academy of Sciences, Bioscience14035) and Sederholm Scholarship Foundation awarded to Burdon and by the Deutsche Forschungs Gemeinschaft DFG (Ju 2856/1-1) awarded to Junker. We would like to thank Magne Friberg for helpful comments, Rachel Vannette for sharing R code and Joseph Anderson for assessing growth models.

Open Access This article is distributed under the terms of the Creative Commons Attribution 4.0 International License (http://creativeco mmons.org/licenses/by/4.0/), which permits unrestricted use, distribution, and reproduction in any medium, provided you give appropriate credit to the original author(s) and the source, provide a link to the Creative Commons license, and indicate if changes were made. 


\section{References}

Aleklett K, Hart M, Shade A (2014) The microbial ecology of flowers: an emerging frontier in phyllosphere research. Botany 92:253266. https://doi.org/10.1139/cjb-2013-0166

Álvarez-Pérez S, Herrera CM, Vega C (2012) Zooming-in on floral nectar: a first exploration of nectar-associated bacteria in wild plant communities. FEMS Microbiol Ecol 80:591-602. https:// doi.org/10.1111/j.1574-6941.2012.01329.x

Álvarez-Pérez S, Lievens B, Jacquemyn H, Herrera CM (2013) Acinetobacter nectaris sp. nov. and Acinetobacter boissieri sp. nov., isolated from floral nectar of wild Mediterranean insect-pollinated plants. Int J Syst Evol Microbiol 63:1532-1539. https:// doi.org/10.1099/ijs.0.043489-0

Bartlewicz J, Lievens B, Honnay O, Jacquemyn H (2016) Microbial diversity in the floral nectar of Linaria vulgaris along an urbanization gradient. BMC Ecol. https://doi.org/10.1186/s1289 8-016-0072-1

Benson DA, Cavanaugh M, Clark K et al (2013) GenBank. Nucleic Acids Res 41:D36-D42. https://doi.org/10.1093/nar/gks1195

Brady CL, Venter SN, Cleenwerck I et al (2009) Pantoea vagans sp. nov., Pantoea eucalypti sp. nov., Pantoea deleyi sp. nov. and Pantoea anthophila sp. nov. Int J Syst Evol Microbiol 59:2339-2345. https://doi.org/10.1099/ijs.0.009241-0

Bulgarelli D, Schlaeppi K, Spaepen S et al (2013) Structure and functions of the bacterial microbiota of plants. Annu Rev Plant Biol 64:807-838. https://doi.org/10.1146/annurev-arplant-05031 2-120106

Burdon RCF, Raguso RA, Kessler A, Parachnowitsch AL (2015) Spatiotemporal floral scent variation of Penstemon digitalis. J Chem Ecol 41:641-650. https://doi.org/10.1007/s10886-015-0599-1

Canto A, Herrera CM (2012) Micro-organisms behind the pollination scenes: microbial imprint on floral nectar sugar variation in a tropical plant community. Ann Bot 110:1173-1183. https://doi. org/10.1093/aob/mcs 183

Coutinho TA, Venter SN (2009) Pantoea ananatis: an unconventional plant pathogen. Mol Plant Pathol 10:325-335. https://doi.org/10. 1111/j.1364-3703.2009.00542.x

Del Giudice L, Massardo DR, Pontieri P et al (2008) The microbial community of Vetiver root and its involvement into essential oil biogenesis: Vetiver root bacteria and essential oil biogenesis. Environ Microbiol 10:2824-2841. https://doi.org/10.111 1/j.1462-2920.2008.01703.x

Dorman HJD, Deans SG (2000) Antimicrobial agents from plants: antibacterial activity of plant volatile oils. J Appl Microbiol 88:308-316. https://doi.org/10.1046/j.1365-2672.2000.00969.x

Dudareva N, Klempien A, Muhlemann JK, Kaplan I (2013) Biosynthesis, function and metabolic engineering of plant volatile organic compounds. New Phytol 198:16-32. https://doi.org/10.1111/ nph. 12145

Effmert U, Kalderás J, Warnke R, Piechulla B (2012) Volatile mediated interactions between bacteria and fungi in the soil. J Chem Ecol 38:665-703. https://doi.org/10.1007/s10886-012-0135-5

Feistner G, Korth H, Ko H et al (1983) Ferrorosamine A from Erwinia rhapontici. Curr Microbiol 8:239-243. https://doi.org/10.1007/ BF01579553

Fridman S, Izhaki I, Gerchman Y, Halpern M (2012) Bacterial communities in floral nectar. Environ Microbiol Rep 4:97-104. https ://doi.org/10.1111/j.1758-2229.2011.00309.x

Good AP, Gauthier M-PL, Vannette RL, Fukami T (2014) Honey bees avoid nectar colonized by three bacterial species, but not by a yeast species, isolated from the bee gut. PLoS One 9:e86494. https ://doi.org/10.1371/journal.pone.0086494
Grenier A-M, Duport G, Pages S et al (2006) The phytopathogen Dickeya dadantii (Erwinia chrysanthemi 3937) is a pathogen of the pea aphid. Appl Environ Microbiol 72:1956-1965. https://doi. org/10.1128/AEM.72.3.1956-1965.2006

Griffin SG, Wyllie SG, Markham JL, Leach DN (1999) The role of structure and molecular properties of terpenoids in determining their antimicrobial activity. Flavour Fragr J 14:322-332. https:// doi.org/10.1002/(SICI)1099-1026(199909/10)14:5<322::AIDFFJ837>3.0.CO;2-4

Hammer KA, Carson CF, Riley TV (1999) Antimicrobial activity of essential oils and other plant extracts. J Appl Microbiol 86:985990. https://doi.org/10.1046/j.1365-2672.1999.00780.x

Hao MV, Brenner DJ, Steigerwalt AG et al (1990) Erwinia persici$n u s$, a new species isolated from plants. Int J Syst Evol Microbiol 40:379-383. https://doi.org/10.1099/00207713-40-4-379

Helletsgruber C, Dötterl S, Ruprecht U, Junker RR (2017) Epiphytic bacteria alter floral scent emissions. J Chem Ecol. https://doi. org/10.1007/s10886-017-0898-9

Herman A, Tambor K, Herman A (2016) Linalool affects the antimicrobial efficacy of essential oils. Curr Microbiol 72:165-172. https ://doi.org/10.1007/s00284-015-0933-4

Herrera CM, García IM, Pérez R (2008) Invisible floral larcenies: microbial communities degrade floral nectar of bumble bee-pollinated plants. Ecology 89:2369-2376. https://doi. org/10.1890/08-0241.1

Höferl M, Buchbauer G, Jirovetz L et al (2009) Correlation of antimicrobial activities of various essential oils and their main aromatic volatile constituents. J Essent Oil Res 21:459-463. https://doi. org/10.1080/10412905.2009.9700218

Huang M, Sanchez-Moreiras AM, Abel C et al (2012) The major volatile organic compound emitted from Arabidopsis thaliana flowers, the sesquiterpene $(E)$ - $\beta$-caryophyllene, is a defense against a bacterial pathogen. New Phytol 193:997-1008. https://doi.org/1 0.1111/j.1469-8137.2011.04001.x

Inglis PW, Burden JL, Peberdy JF (1996) Evidence for the association of the enteric bacterium Ewingella americana with internal stipe necrosis of Agaricus bisporus. Microbiology 142:3253-3260. https://doi.org/10.1099/13500872-142-11-3253

Jacquemyn H, Lenaerts M, Tyteca D, Lievens B (2013) Microbial diversity in the floral nectar of seven Epipactis (Orchidaceae) species. MicrobiologyOpen 2:644-658. https://doi.org/10.1002/ mbo3.103

Johnson KB, Stockwell VO, Sawyer TL, Sugar D (2000) Assessment of environmental factors influencing growth and spread of Pantoea agglomerans on and among blossoms of pear and apple. Phytopathology 90:1285-1294. https://doi.org/10.1094/PHYTO .2000 .90 .11 .1285

Junker RR, Bluthgen N (2008) Floral scents repel potentially nectarthieving ants. Evol Ecol Res 10:295

Junker RR, Parachnowitsch AL (2015) Working towards a holistic view on flower traits-how floral scents mediate plant-animal interactions in concert with other floral characters. J Indian Inst Sci 95:43-68

Junker RR, Tholl D (2013) Volatile organic compound mediated interactions at the plant-microbe interface. J Chem Ecol 39:810-825. https://doi.org/10.1007/s10886-013-0325-9

Junker RR, Loewel C, Gross R et al (2011) Composition of epiphytic bacterial communities differs on petals and leaves: bacterial communities on flowers and leaves. Plant Biol 13:918-924. https://doi. org/10.1111/j.1438-8677.2011.00454.x

Junker RR, Romeike T, Keller A, Langen D (2014) Density-dependent negative responses by bumblebees to bacteria isolated from flowers. Apidologie 45:467-477. https://doi.org/10.1007/s1359 2-013-0262-1 
Kahm M, Hasenbrink G, Lichtenberg-Fraté H et al (2010) Grofit: fitting biological growth curves with R. J Stat Softw 33:1-21. https://doi. org/10.18637/jss.v033.i07

Kamatou GPP, Viljoen AM (2008) Linalool - a review of a biologically active compound of commercial importance. Nat Prod Commun 3:1183-1192

Kamber T, Smits THM, Rezzonico F, Duffy B (2012) Genomics and current genetic understanding of Erwinia amylovora and the fire blight antagonist Pantoea vagans. Trees 26:227-238. https://doi. org/10.1007/s00468-011-0619-x

Kessler D, Baldwin IT (2007) Making sense of nectar scents: the effects of nectar secondary metabolites on floral visitors of Nicotiana attenuata: function of floral secondary metabolites. Plant $\mathrm{J}$ 49:840-854. https://doi.org/10.1111/j.1365-313X.2006.02995.x

Kleinheinz GT, Bagley ST, John WS et al (1999) Characterization of alpha-pinene-degrading microorganisms and application to a bench-scale biofiltration system for VOC degradation. Arch Environ Contam Toxicol 37:151-157. https://doi.org/10.1007/s0024 49900500

Knudsen JT, Eriksson R, Gershenzon J, Ståhl B (2006) Diversity and distribution of floral scent. Bot Rev 72:1-120. https://doi. org/10.1663/0006-8101(2006)72[1:DADOFS]2.0.CO;2

Lenaerts M, Álvarez-Pérez S, de Vega C et al (2014) Rosenbergiella australoborealis sp. nov., Rosenbergiella collisarenosi sp. nov. and Rosenbergiella epipactidis sp. nov., three novel bacterial species isolated from floral nectar. Syst Appl Microbiol 37:402-411. https://doi.org/10.1016/j.syapm.2014.03.002

Lievens B, Hallsworth JE, Pozo MI et al (2015) Microbiology of sugarrich environments: diversity, ecology and system constraints: microbiology of sugar-rich environments. Environ Microbiol 17:278-298. https://doi.org/10.1111/1462-2920.12570

Lindow SE, Brandl MT (2003) Microbiology of the phyllosphere. Appl Environ Microbiol 69:1875-1883. https://doi.org/10.1128/ AEM.69.4.1875-1883.2003

Martínez-Rodríguez del JC, Mora-Amutio MDL, Plascencia-Correa LA et al (2014) Cultivable endophytic bacteria from leaf bases of Agave tequilana and their role as plant growth promoters. Braz $\mathrm{J}$ Microbiol 45:1333-1339. https://doi.org/10.1590/S1517-83822 014000400025

McArt SH, Koch H, Irwin RE, Adler LS (2014) Arranging the bouquet of disease: floral traits and the transmission of plant and animal pathogens. Ecol Lett 17:624-636. https://doi.org/10.1111/ ele. 12257

Parachnowitsch AL, Raguso RA, Kessler A (2012) Phenotypic selection to increase floral scent emission, but not flower size or colour in bee-pollinated Penstemon digitalis. New Phytol 195:667-675. https://doi.org/10.1111/j.1469-8137.2012.04188.x

Parachnowitsch AL, Burdon RCF, Raguso RA, Kessler A (2013) Natural selection on floral volatile production in Penstemon digitalis: highlighting the role of linalool. Plant Signal Behav 8:e22704. https://doi.org/10.4161/psb.22704

Queiroga CL, Teixeira Duarte MC, Baesa Ribeiro B, de Magalhães PM (2007) Linalool production from the leaves of Bursera aloexylon and its antimicrobial activity. Fitoterapia 78:327-328. https://doi. org/10.1016/j.fitote.2007.03.012

R Core Team (2017) R: a language and environment for statistical computing. R Foundation for Statistical Computing, Vienna

Rering C, Beck JJ, Hall GW et al (2017) Nectar-inhabiting microorganisms influence nectar volatile composition and attractiveness to a generalist pollinator. New Phytol. https://doi.org/10.1111/ nph.14809
Samuni-Blank M, Izhaki I, Laviad S et al (2014) The role of abiotic environmental conditions and herbivory in shaping bacterial community composition in floral nectar. PLoS One 9:e99107. https:// doi.org/10.1371/journal.pone.0099107

Sansores-Peraza P, Rosado-Vallado M, Brito-Loeza W et al (2000) Cassine, an antimicrobial alkaloid from Sennaracemosa. Fitoterapia 71:690-692. https://doi.org/10.1016/S0367-326X(00)00152-0

Santos M, Diánez F, Miñano J et al (2009) First report of Erwinia aphidicola from Phaseolus vulgaris and Pisum sativum in Spain: new disease reports. Plant Pathol 58:1171-1171. https://doi.org/ 10.1111/j.1365-3059.2009.02106.x

Satomi M (2006) Bacillus safensis sp. nov., isolated from spacecraft and assembly-facility surfaces. Int J Syst Evol Microbiol 56:17351740. https://doi.org/10.1099/ijs.0.64189-0

Schaeffer RN, Irwin RE (2014) Yeasts in nectar enhance male fitness in a montane perennial herb. Ecology 95:1792-1798. https://doi. org/10.1890/13-1740.1

Schmidt E, Jirovetz L, Buchbauer G et al (2005) Antimicrobial testings and gas chromatographic analyses of aroma chemicals. J Essent Oil Bear Plants 8:99-106. https://doi.org/10.1080/09720 60X.2005.10643427

Sessitsch A, Reiter B, Berg G (2004) Endophytic bacterial communities of field-grown potato plants and their plant-growth-promoting and antagonistic abilities. Can J Microbiol 50:239-249. https:// doi.org/10.1139/w03-118

Taniguchi S, Hosokawa-Shinonaga Y, Tamaoki D et al (2014) Jasmonate induction of the monoterpene linalool confers resistance to rice bacterial blight and its biosynthesis is regulated by JAZ protein in rice. Plant Cell Environ 37:451-461. https://doi. org/10.1111/pce.12169

Theis N, Lerdau M, Raguso RA (2007) The challenge of attracting pollinators while evading floral herbivores: patterns of fragrance emission in Cirsium arvense and Cirsium repandum (Asteraceae). Int J Plant Sci 168:587-601. https://doi.org/10.1086/513481

Vannette RL, Fukami T (2016) Nectar microbes can reduce secondary metabolites in nectar and alter effects on nectar consumption by pollinators. Ecology 97:1410-1419. https://doi. org/10.1890/15-0858.1

Vannette RL, Gauthier M-PL, Fukami T (2013) Nectar bacteria, but not yeast, weaken a plant-pollinator mutualism. Proc R Soc Lond B Biol Sci 280:20122601. https://doi.org/10.1098/rspb.2012.2601

Wright GA, Schiestl FP (2009) The evolution of floral scent: the influence of olfactory learning by insect pollinators on the honest signalling of floral rewards. Funct Ecol 23:841-851. https://doi.org/ 10.1111/j.1365-2435.2009.01627.x

Yang C-H, Crowley DE, Borneman J, Keen NT (2001) Microbial phyllosphere populations are more complex than previously realized. Proc Natl Acad Sci 98:3889-3894. https://doi.org/10.1073/ pnas.051633898

Zajdel S, Graikou K, Głowniak K, Chinou I (2012a) Chemical analysis of selected Penstemon species and their antimicrobial activity. Planta Med. https://doi.org/10.1055/s-0032-1321020

Zajdel SM, Graikou K, Głowniak K, Chinou I (2012b) Chemical analysis of Penstemon campanulatus (Cav.) Willd.-antimicrobial activities. Fitoterapia 83:373-376. https://doi.org/10.1016/j.fitot e.2011.11.021

Zajdel SM, Graikou K, Sotiroudis G et al (2013) Two new iridoids from selected Penstemon species-antimicrobial activity. Nat Prod Res 27:2263-2271. https://doi.org/10.1080/14786419.2013.825913 